\title{
THE FRUSTRATION OF STATE MEDICINE
}

\author{
1880-1899
}

by

ROY M. MACLEOD

The aim of this Department has always been to secure a basis of scientific principle for the sanitary practice of the country; to found recommendations for the maintenance of health in the community upon the teachings of physiology and medicine; and to conduct investigations into disease and its causes by the light of the best contemporary knowledge of pathology. By firm adherence to this method Mr. Simon came to direct a medical department which, while fulfilling important duties to the Government, had the complete confidence of sanitary workers throughout England and abroad, and brought the knowledge of hygienic science to a high point of public usefulness. It would be a disaster to sanitary progress as well as a serious misfortune to the Board, if your Medical Officer should, by reason of his utter preoccupation in routine business, lose sight of the true aim of his office, and cease to guide his Department by the only trustworthy principles of sanitary action.

-Dr. George Buchanan to Sir Charles Dilke, 17 November 1883.

\section{INTRODUCTION ${ }^{1}$}

IN 1898, a quarter-century of criticism and uncertainty about the alleged inefficiency of the Local Government Board in public health affairs came to a head. In this year, following repeated attempts by the Local Government Board for over a decade to institute formal scrutiny of the department in its relation to Government and the public, a Departmental Committee of Inquiry was appointed by the Treasury. ${ }^{2}$ After receiving extensive evidence, the Committee agreed conclusively that the department had been overworked and underpaid for years; that outmoded administrative practices had reduced the Board to apparent somnolence; and that morale within the Department had almost completely collapsed. Sir Richard Thorne-Thorne, representing the Medical Department, concurred that the central administration of State medicine had been reduced to a living shadow. But the history of the Department, as outlined in Thorne-Thorne's evidence, scarcely revealed the causes of this sad and invidious decline.

In the mid-seventies, the factors prophetic of decay were thought reasonably

1 This investigation was supported in part by assistance from the Wellcome Trust and by USPHS Grant No. 5-F1-MH-23, $115-02$ from the National Institute of Mental Health. I am grateful to Dr. Richard Thorne-Thorne, of Weybridge, Surrey, for information about his father; to Lord Balerno, of the House of Cockburn, Balerno, Midlothian, for the use of his Memoir of the Buchanan Family, and in particular of George Buchanan, 1831-1895, (printed privately, Aberdeen University Press, 1941); and to Sir Arthur MacNalty, for his early advice and for the background material made available in his 'History of State Medicine in England', The Fitzpatrick Lectures, 1947, especially Lecture 3, 'The Medical Department of the Local Government Board', J. R. Inst. publ. Hlth., II (January, 1948), pp. 9-26.

Report of the Departmental Committee appointed to inquire into the sufficiency of the Clerical Staff and Secretariat of the Local Government Board, 1898. [C.8731]. xl.429. 


\section{R. M. MacLeod}

clear. ${ }^{3}$ The duel between John Simon and John Lambert was widely represented as a contest between the aggressive methods of a medical innovator and the 'Poor Law mentality' of the professional administrator. In some measure, this infra-departmental conflict was considered to have determined the course of British state medicine until the turn of the century. Recent work, however, has suggested that the difficulties besetting state medicine cannot be so categorically summarized; that the problem must be seen in the context of central-local government relations and with reference to urban vs rural sanitary policy; and that the administrative connection between the sanitary authorities and the destitution authorities may not have been the only, or even the most obstructive factor in the Board's development."

A complete re-appraisal of those time-worn assumptions which Simon's English Sanitary Institutions have kept alive through the years ${ }^{5}$ must await a careful study of late-century administrative policy as a whole. However, it may be useful at present to emphasize some less discussed factors which influenced the Medical Department after Simon. One such factor is that of Gladstonian finance. Whether operative directly by Treasury refusal to sanction, or indirectly by the exertion of moral pressure on permanent staffs, the Treasury's concern to prevent excessive expenditure was reflected in the day-to-day operations of all Victorian departments. Since the Treasury files for this period have rarely been studied it is not surprising that so little recognition has been given to the effects of economic restriction upon the efficiency, the morale and the conduct of the Medical Department. An analysis of Treasury out-letters and internal minutes during the period 1880-1900 suggests not only a new and slightly different interpretation of events, but also reveals the emergence of an implicit harmony between the secretariat and the doctors, and the making of common cause against the demoralising effects of Treasury control. ${ }^{6}$ In this light, the experience of the Medical Department illuminates a large sector of Victorian departmental activity and offers fresh insight into the effect of administrative procedure upon scientific and technical priorities during the closing years of the so-called 'nineteenth-century

\footnotetext{
- Thus, the Lancet wrote, 'Mr. Stansfeld made the public health administration of the country a mere branch of Poor Law administration, and it remains so at the present day, to the scandal of the Legislature and the public'. Lancet, $1875, i, 134 . \therefore$ we have no hesitation in saying that a quarter of a century will hardly suffice to undo the mischievous futilities of local sanitary administration and the increasing prejudice of local authorities to detailed sanitary work, for which the Local Government Board is wholly responsible'. Lancet, 1875, i, 239. See also John Simon, English Sanitary Institutions, (London, 1890), Chapter XV; and Sir Arthur Newsholme, The Last Thirty Years in Public Health, (London, 1936), Chapter V.

- For an excellent discussion of Simon and the origins and early years of the Local Government Board, see Royston Lambert, Sir John Simon and English Social Administration, (London, 1963). See also, Jeanne Brand, 'John Simon and the Local Government Board Bureaucrats, 1871-1876', Bull. Hist. Med., 1963, 37, 184-194. There is no satisfactory biography of John Lambert, but details of his active career may be found in MH 18/207, H. Owen to Treasury, 27 November 1881, and in the Treasury papers confirming his pension. His character is revealed best by a reading of Local Government Board records and office minutes.

B Cf. M. Morris, The Story of English Public Health, (London, 1919); C. F. Brockington, Short History of Public Health, (London, 1956); W. M. Frazer, History of English Public Health, (London, 1950); Sir George Newman attempted to keep the issues of disagreement quite clear, but himself conveyed an implicit assumption that there was no difference between a 'reinstatement of the old Poor Law Board', and normative Victorian administrative departmentalism. See Newman, The Building of a Nation's Health, (London, 1939), p. 23.

- The nature of that tension and its relation to the overall experience of the Civil Service is suggested in my forthcoming monograph 'Treasury Control and Social Administration, 1871-1906: A Case Study in Establishment Growth and Administrative Fatigue', Occasional Papers in Social Administration, London School of Economics, Winter, 1966-1967.
} 
revolution in government'. ${ }^{7}$ This essay will discuss these effects upon the tenures of two Medical Officers, Dr. (later Sir George) Buchanan, 1880-1892, and Dr. (later Sir Richard) Thorne-Thorne, 1892-1899. ${ }^{8}$

\section{THE FRUSTRATION OF MEDICAL INSPECTION}

It will be recalled that, in the spring of 1876 , ostensibly because of John Lambert's refusal to request Treasury sanction for three additional medical inspectors, John Simon resigned from government service. ${ }^{9}$ Simon bequeathed to his successors an administrative apparatus as yet partial and incomplete. Although vaccination inspection had been systematized, it had proved impossible to institute a comprehensive national system of sanitary inspection. The Department had only its Medical Officer, Dr. Seaton, ${ }^{10}$ his Assistant Medical Officer, George Buchanan, and nine Inspectors. ${ }^{11}$ Seaton himself was relegated to a subordinate position analogous to that of the Chief Engineering Inspector, in which he was merely to 'arrange as to the inspections to be undertaken under the direction of the Board by the Medical Inspectors, to examine their reports, and advise the Board upon them, to superintend generally the medical staff, and all matters relating to vaccination. ${ }^{12}$ Despite these limited terms of reference, the Medical Officer struggled to keep pace with the tide of sanitary neglect throughout the country. ${ }^{13}$ But even with the good graces of the Board, these efforts were unavailing against the restrictive policies of Treasury control.

In December 1876, Lambert tried to ease tensions between his administration and the medical staff by asking Treasury sanction to increased salaries for Drs. Seaton, Stevens, Thorne-Thorne and Ballard. The attempt was frustrated, however, by the Treasury's unwillingness to consider raising salaries which 'were originally fixed at a higher figure than they would otherwise have been, because of their previous official employment, special qualifications, and professional position.'14 This refusal deprived Seaton himself of $£ 100$ p.a. for administering the Department's scientific research work, ${ }^{15}$ and reduced his salary from the $£ 2,000$ enjoyed by Simon to $£ 1,200$.

In the following months the Treasury reacted strongly against such practices as the gratuitous distribution of Medical Department reports, and the use of expensive

7 For the classic discussion of this revolution in public policy, see Oliver MacDonagh, 'The Ninteenth-Century Revolution in Government; A Re-appraisal', Historical Journal, 1958, i, 52-67; this theme is amplified in Royston Lambert's Simon, and has most recently been summarized in Valerie Cromwell's 'Interpretations of Nineteenth-Century Administration: An Analysis', Victorian Studies, 1966, 9, 245-55.

A sequel to this paper will deal with the early years of the present century, the 'new Liberalism' and the work of Sir Arthur Newsholme.

- MH. 19/211. Lambert to Treasury, 23 March 1876.

10 Edward Cator Seaton (1815-1880); educated in the medical schools of Edinburgh and Paris; conducted private practice in Rochester and London, one of founders of Epidemiological Society; an eminent specialist on vaccination; at the Medical Department from 1859; one of the British representatives at the International Sanitary Conference in Vienna, 1874. Lancet, 1880, $\mathbf{i}, 188-89$. The Times, 4 June 1876.

11 Seaton's own vacancy was left unfilled. The nine inspectors included Drs. Franklin Parsons, Richard Thorne-Thorne, William Power, Edward Ballard, Henry Stevens, J. Netten Radcliffe and Frederick Blaxall.

18 MH 19/211. Lambert to Treasury, 6 April 1876.

18 'Eleven months experience in the present duties of my office', Seaton sadly minuted, 'enable me to state that these have taxed me more than I had anticipated ... partly because the business of the Department has been greatly increasing'. MH 19/212. Seaton minute, 31 January 1877.

14 MH 19/212-W. H. Smith to Lambert, 31 January 1877.

16 MH 19/211-Lambert to Treasury, 23 March 1876. 


\section{R. M. MacLeod}

lithographs and illustrations, despite objections that this would limit the usefulness of such documents to the officials of both central and local government. ${ }^{16}$ By the autumn of 1877, pursuing the retrenchment policies recommended by the Committee on Civil Service Expenditure in $1873,{ }^{17}$ the Treasury had set itself against every attempt by Lambert or the doctors to give additional recognition to the Medical Department. '[My Lords] cannot admit', wrote William Law, 'that any of the members of the medical part of your establishment have well-founded grievances, or serious disappointment, to complain of' ${ }^{18}$ In 1878, the Treasury even attempted to solicit fees from Local Authorities for inspections, and to deny laboratory assistance to the medical inspectors. ${ }^{19}$ The medical press saw the Department as suffering from 'official Thuggism', and blamed the Local Government Board secretariat for 'preparing the ligature with which it proposes ultimately to strangle its Medical Department, as originally conceived ... . before the infatuated alliance with Poor-Law administration.'20 Yet during all these years of negotiation, Lambert gave every evidence of being alive to the necessity for an efficient organ of medical administration. ${ }^{21}$ It is at least arguable that Simon's departure, by removing Lambert's chief rival, permitted Lambert the opportunity to operate on the Department's behalf in his own methodical way. Unhappily, even the best administrative methods were often inadequate to the task.

In 1881, Seaton died from ill-health and overwork. In June 1882, three years after succeeding him, Dr. George Buchanan ${ }^{22}$ expressed grave apprehension about the state of public medicine, and asked for additional medical staff. Routine vaccination

16 'When the Treasury speak lightly of the duties which the administration of this grant involves they surely cannot have considered in what this administration consists. It does not consist in the mere editing of reports (the critical scientific editing demands no little labour) but it involves weighing and advising on the subjects to be taken in hand, judgement on the course of investigations proposed to be pursued, and intimate communication with the individuals who are carrying out the several inquiries.' MH 19/212. Seaton minute, 31 January 1877. MH 19/212, G. Buchanan to Lambert, 4 September 1877, 1000 copies of the Medical Officer's Report were issued, of which 400 were reserved for Parliament, 400 for the L.G.B., and 200 for general purchase. The latter were sold out within a fortnight of issue. Ibid., Seaton to Lambert, 22 July 1878.

${ }_{17}$ Third Report, Select Committee on Civil Expenditure, 1873, (352). vii.415.

18 MH 19/212, William Law to Lambert, 6 September 1877.

${ }^{19} \mathrm{MH}$ 19/212. Owen to Secretary, Treasury, 15 February 1878. Lambert to Treasury, 4 April 1878. On the first issue, the Treasury was defeated by Lambert's taking the matter to the Law Officers of the Crown. Afterwards, he exulted to Sclater-Booth, 'the conversion of their lordships and the candour with which it is expressed will probably be as satisfactory to you as the opinion now given ..... Lambert to President, 29 November 1878.

${ }^{20}$ Lancet, 1879, i, 201.

21 In December 1880, Lambert made an appeal for an increase in the departmental estimates for 1881-82 for funds to 'induce Boards of Guardians to assign adequate salaries to their Medical Officers, in order that the sick poor may receive proper attention'. MH 19/213. Minute, Lambert, 2 December 1880. In February 1881, Lambert criticized the Treasury's benign contention that the River Conservancy Bill then under consideration would require no increase in funds, and pointedly remarked that, as the Bill was prepared by order of a Select Committee of the House of Lords, the Board was not "culpable" for any necessary increase. His letter was made the subject of a formal scolding by Ralph Lingen, Permanent Secretary of the Treasury, on the subject of departmental responsibility and Treasury control. Ibid., Lingen to President, 15 February 1881.

${ }^{22}$ George Buchanan (1831-1895), F.R.S.; University College, London, M.D.; F.R.C.P.; consultant to London Fever Hospital and Hospital for Sick Children; active in Senate of University of London, Society of Medical Officers of Health and Epidemiological Society. M.O.H. St. Giles, 1866-69; Medical Inspector at Privy Council, 1869-71; Assistant Medical Officer, 1871-80; Medical Officer, 1880-92; LL.D. Edinburgh, 1893; Gold Medal of Royal Society, 1894; Married, first, Mary, sister of Shirley Murphy, famous M.O.H. for the London County Council; and second, Alice, daughter of Dr. E. C. Seaton Brit. med. J. 1895, i, 1066-67; Lancet, 1895, i, 1224-25. 


\section{The Frustration of State Medicine, 1880-1899}

work, for many years the most fundamental preventive medical service, continued to require the full-time equivalent of four inspectors. Inquiries into local sanitary matters, local byelaws, and the circumstances of epidemics consumed the time of another three or four men. The entire staff was thus so fully occupied that time for special inquiries ${ }^{23}$ of national importance could be made only by subtracting time from day-to-day administration. Even special studies arising from serious epidemics 'were not made except by allowing the current inspection of vaccination to fall into nearly a year's arrears in part of Dr. Thorne's and Mr. Power's district'. ${ }^{24}$ Other work of great importance, like Mr. William Power's study of 'aerial spread' from the Fulham smallpox hospital, and the Department's regional surveys of scarlet fever fatality, were postponed indefinitely. For none of this postponement, Buchanan insisted, could the Inspectors be blamed. On the contrary,

of the several inspectors it is my duty to say that no men could work harder or with better system, or with greater desire to do their best. Except vaccination inspection, which is done rapidly, it is impossible from the very nature of the Inspector's work that it should be done at high speed; the business does not consist in the mere application of a number of known principles to readily recognized conditions, but in a multitude of personal investigations which have to be pushed in one direction after another, and to be reasoned from as the inquiry progresses. ${ }^{25}$

While survey work in the field was difficult, the administrative work in Whitehall threatened to become overbearing. In the twenty-nine months between October 1878 and February 1881, the Medical Department drafted, discussed and issued 119 circulars, memoranda, and reminders to Local Sanitary Authorities, Medical Officers of Health and Boards of Guardians. ${ }^{26}$ Both Buchanan and his Assistant Medical Officer, J. Netten Radcliffe, customarily worked overtime six days a week. Yet, the Annual Report of the Medical Department was delayed year after year, and the medical press frequently complained that Buchanan had no time to 'discuss at length any one subject of public health in the broad catholic spirit that illuminated Mr. Simon's blue books'. ${ }^{27}$ The sheer weight of administration inhibited creative thinking; men who spent their days preoccupied with routine matters could not be expected to plan large schemes for the public good. 'I regard as the most important of all my duties', Buchanan insisted,

23 Such as Dr. Thorne-Thorne's inquiry into the usefulness of infectious diseases isolation hospitals; the study of Drs. Ballard and Power on infantile diarrhoea; and Dr. Blaxhall's work on the lodging of emigrants. Thorne-Thorne's study (in the 10th Annual Report) was initially issued in 775 copies, of which 300 were for the Board's use, 250 were for distribution by the Medical Department, and 225 were placed on sale. At the same time, there were 1600 Medical Officers of Health who, in Thorne-Thorne's opinion, should have received a copy free of charge. Thorne-Thorne therefore requested Treasury sanction for fifty additional copies, which was reluctantly granted. This additional distribution was nonetheless regarded by Buchanan as quite inadequate. MH 19/214. Thorne-Thorne, for Medical Officer, to Rotton, 19 September 1882.

24 Moreover, in the North of England, owing to Dr. Beard's illness, vaccination inspection had fallen six months behind. See T.1/8298 A/6204/1887. Representations made by the Medical Department of the Local Government Board, November 1883, pp. 3, 5 .

25 Ibid., p. 4.

26 This compared with sixty-two such circulars and memoranda issued by the Privy Council Medical Department in the five years, 1866-71; with fifty-odd issued during the three-year period, August 1871-August 1874; and with the seventy-odd issued during the four years August 1874September 1878; in other words, this represented an increase of about $300 \%$ since Buchanan took office. (Calculated from Departmental files, Ministry of Health).

${ }^{27}$ Brit. Med. J., 1882, i, 124. 


\section{R. M. MacLeod}

the planning of the work of the Inspectors, the constant council that I take with them, the criticism I give to their inquiries and reports; in brief, the leadership of the Board's medical staff. In this view, I am sure the Board and Inspectors alike will agree with me. I, as Medical Officer, in turn profit by all this, and should be less qualified for the service of the Board if I in any degree abridged or omitted this part of my functions. ${ }^{28}$

When Local Authorities looked for 'encouragement, instruction, and guidance', 29 they often looked in vain. Work, Buchanan confessed, was too often 'delayed where it should be expedited' and that 'whatever can be regarded as less urgent is left to accumulate. ${ }^{30}$

This anguished appeal met a dispiriting response. Lambert agreed to request Treasury sanction for additional help, but knowing the Treasury's attitude, agreed to do so only for temporary appointments. ${ }^{31}$ In April 1883, Buchanan again requested a second Assistant Medical Officer and two additional Medical Inspectors. In the preceding year, the retirement of some of the older administrative staff and the acquisition of several younger clerks had ended some of the 'poor law dominance' that had plagued the Board's early years. ${ }^{32}$ Lambert had been succeeded by Hugh Owen, a former Poor Law Clerk, but a man noted in the 'eighties for his cordiality and efficiency. ${ }^{33}$ Moreover, the new Liberal President, Sir Charles Dilke, possessed

${ }_{28}$ T.1/8298A/6204/1887, Representations, November, 1883, p. 5.

29 Lancet, 1879 , ii, 323.

30 T.1/8298A/6204/1887, Representations, p. 5.

31 At this, Buchanan's anger flared. Admittedly 'not always at pains to conceal his impatience with politicians who failed to realize the importance of [his] work', Buchanan seems often to have annoyed his administrative and political superiors. When, in 1882, Lambert announced his intention to retire on grounds of ill-health, Buchanan undoubtedly urged T. Rotton, Assistant Secretary of the Board and former Legal Adviser to the old Privy Council Medical Department, to apply for the position, and protested against the appointment of Hugh Owen, another former Poor Law Board clerk, to the permanent secretaryship. Lambert observed: 'I am not sure that some of his medical friends may not have stimulated him to write as he has done, as I know they are very much put out by your refusal to make a permanent addition to the staff of inspectors'. Monk Bretton Papers (The Bodleian), Dep. 52, Lambert to Dodson, 25 November 1882. One of Buchanan's biographers later noted deep seated distrust and resentment reflected in the candid minutes of the otherwise selfsacrificing Medical Officer: 'It must be admitted that he never cared to go out of his way to conciliate the statesmen who were successively his political chiefs; he never hesitated to tell them what they should do, and the frankness with which he expressed his views occasionally caused a little friction between him and the superior powers', Brit. Med. J., 1895, i, 1067.

${ }_{82}$ Ernest Hart believed that the 'regressive prejudices of a poor-law career' were gradually breaking down, and that much could be sought in the department now 'administered wholly by what may be called "young men".' Brit. Med. J., 1883, ii, 386.

${ }^{33}$ Herbert Preston Thomas, once a clerk in the Medical Department and later a General Inspector, commented, '[Owen] seemed to know more of inspecting than most inspectors, more of law than most lawyers, much more of the principles of administration than the Ministers under whom he served ... He was always prompt in the despatch of business ... and he would, I am confident, at any time have resigned rather than carry out a policy of which he disapproved. His memory was almost unsurpassingly attentive'. Preston Thomas, The Work and Play of a Government Inspector, (Edinburgh, 1909), p. 200. Viscount Long, Parliamentary Secretary to the Board, 1886-92, and President, 1900-1905, later remembered Owen as 'one of the ablest and most industrious Civil Servants, and one of the kindest men - a veritable "mine of knowledge"; if he had any failing it was that he insisted on doing too much himself, the result being that the work was delayed', Walter Long, Memories, (London, 1923), pp. 94-95. For testimonials to his devoted and co-operative service, see the speech by Sir Charles Dilke to the National Poor Law Officers Association, 1899, in the Local Government Chronicle, 1899, pp. 298-99. Sir Arthur Newsholme, one of the most severe critics of exclusive secretarial administration of public health, admitted that Owen was 'an astute and able lawyer and for years held his post with supreme ability'. Under Owen's administration, the secretarial influence continued to dominate health affairs, but the old Poor Law Office domination per se became a thing of the past. These two parallel but distinct factors were confused by Newsholme, and the confusion has since been magnified by repetition. See Newsholme, The Last Thirty Years in Public Health, (London, 1936), pp. 48-50. 


\section{The Frustration of State Medicine, 1880-1899}

a reputation for the determined action ${ }^{34}$ that circumstances clearly required. Statistics showed that infectious diseases were spreading unchecked through several school areas, and a typhus epidemic in the north of England threatened to make a mockery of the Medical Department. For lack of sufficient staff, even the Poor Law Medical Inspector, Dr. Bridges, had been seconded to the Medical Department. Reacting to each emergency as it arose, Buchanan was unable to make arrangements for the current year's scientific research; ${ }^{\mathbf{3 5}}$ Moreover,

to add no more to the melancholy list, my annual report for the past year cannot be thought of. Yet, Dr. Thorne-Thorne and myself are working as hard as we can at the office, and the whole inspecting staff is doing its best, attending to day-by-day business that engrosses the whole of our time. ${ }^{86}$

To Buchanan the causes of this decline were as clear as their remedy. Severe Treasury control of the number and salaries of medical staff, which had been offset by Simon's tactics and by the privileged status of the Privy Council Office, was now reasserting its full power.

Receiving no reply to his appeal, Buchanan informed the President that the Medical Department was not functioning adequately in the national interest. The Department, he said, was unable to conduct or apply new epidemiological and bacteriological research to the service of society.

... for the last year or two the daily work of the Department has had to be done at too high speed to be done properly, more and more of it has been postponed, and more and more has been left undone. At the same time other departments within the Board, other departments of Government, and all local governments have been inconvenienced by the delays and errors that arise. ${ }^{\text {n? }}$

Nowhere was this more evident than in the case of public vaccination, where, because of the reassignment of Inspectors from vaccination duties to urgent infectious diseases inquiries,

an irregular time is allowed to elapse between successive visits to a district, and Guardians and their officers as well as the public are beginning to suppose that the Board is less solicitous about vaccination than it formerly was. ${ }^{28}$

${ }^{84}$ Lancet, 1882, ii, 1324. 'A fatal narcotism', the Lancet remarked, seems to fall on the brains of ministers who take office in this department; ' . . . the utmost that seems reasonable is to express an earnest hope that where other good and true men have conspicuously failed, the talented and outspoken Member for Chelsea may make his influence felt and succeed'. Lancet, 1883, i, 27.

${ }^{85}$ In 1865, the Privy Council Medical Department had begun investigations into the nature and causation of infectious disease, under the initiative of John Simon and the auspices of an annual Treasury grant. This grant was analogous to those awarded to the Admiralty for studies in astronomy and meteorology. The Medical Department studies were formally designated "Auxiliary Scientific Investigations' in the Estimates for 1870-71, and continued in some form until 1919. Under this grant, Drs. Klein, Burdon, Sanderson, Creighton and others, studied the etiology of anthrax, gonorrhoea, septic typhoid fever, tuberculosis, diphtheria, cholera, tetanus, Malta fever, meningitis, pneumonia, plague and dysentery. See Sir John Charles, Research and Public Health (London, 1961), pp. $84 \mathrm{ff}$. Simon justified the work to the Treasury in view of its 'great and increasing interest to the practical objects of medicine, preventive and curative', and because such systematic researches 'which are of most national importance' were 'not likely in this country to be prosecuted to any adequate extent by private medical investigations'. P.C. 8/210. J. Simon to Clerk of Council, 31 March 1874.

se T.1/8298A/6204/1887, Minute, Buchanan to Dilke, 25 April 1883. Dr. Richard Thorne-Thorne had by now been promoted to fill Radcliffe's post of Assistant Medical Officer. Thorne was replaced by David Page, formerly M.O.H. for Westmorland. Lancet, 1883, i, 1139.

${ }^{87}$ Ibid., Medical Officer, 6 August 1883. T.1/8298A/6204/1887.

${ }^{88}$ T.1/8298A/6204/1887. Minute, Medical Officer, 6 August 1883. For a discussion of this sentiment, see R. MacLeod, 'Law, Medicine, and Public Opinion: The Reaction to Compulsory Vaccination, 1871-1907', Public Law, Spring, 1967. 


\section{R. M. MacLeod}

Even the work of local sanitary supervision was falling into disrepair, despite the fact that more Local Authorities were coming to the Department for advice. ${ }^{39}$ Again and again the Board had 'the mortification of seeing matters go on badly which it could have righted by making use of its Medical Department, if that had been available. ${ }^{40}$ The effects of inadequate research and inspection were aggravated by the inadequate means of distributing what information was available. In June 1883, one Medical Officer of Health asked to be provided regularly with the annual Medical Officer's Report. Buchanan informed Owen that the current edition was exhausted and added thoughtfully:

Do you think this application from an intelligent M.O.H. might well raise the larger question whether health officers who have occasion for these volumes ought not to receive them on application? The more we trust and expect people to do what they ought to do, the more reason there is for showing them what their duty is, and the way of doing it; and a health officer to whom shillings are of consequence and whose S.A. would not think of purchasing a book for him, wants aid and models and instruction which as our reports afford ... Such a man, when our inspectors visit his district, puts time and brains at our disposal, and is at all times prepared to give time and trouble to answer all questions put to him for the sake of knowledge beyond mere sanitary administration.

Of course we shall hear that the reports cannot thus be given away except at some great cost, but their value would be more amply returned in the form of increased efficiency of Medical Officers of Health. ${ }^{41}$

All these difficulties had a predictably damaging effect on the morale of the Medical Inspectors, for whom Buchanan asked immediate and substantial salary increases. ${ }^{42}$ On the question of additional reports, Owen quickly concurred and submitted a request for an additional 100 copies, which was eventually granted. ${ }^{43}$ But on professional salaries he was unable to help, because the Board had recently submitted claims for the clerical staff, which were still under negotiation.

In November 1883, Buchanan solicited the President's personal intervention, on the grounds that it would be

a disaster to sanitary progress as well as a serious misfortune to the Board, if your Medical Officer should, by reason of his utter preoccupation in routine business, lose sight of the true aim of his office, and cease to guide his Department by the only trustworthy principles of sanitary action. ${ }^{44}$

In 1884 , assisted by the timely appearance of cholera on the continent, Buchanan

89 'Communities seek more often to apply to their own use the knowledge that the Board's Medical Inspectors have accumulated, offering in return fresh experience if the Board will send a medical inquirer to gather it.' T.1/8298 A/6204/1887. Minute, 6 August 1883.

${ }^{40}$ Ibid. During the year 1882-83, twenty medical districts had been inspected but twenty-three other districts had been postponed and eleven more were asking for attention. Special scientific studies were two to three years behind; and the illness of one inspector had brought the Department's diphtheria research to a halt.

${ }^{41}$ MH 19/215. Buchanan to J. T. Hibbert, 7 June 1883.

42 No adjustment had been made since 1867, when additional Inspectors were hired for vaccination work at salaries on the scale of $£ 500$-[four years]- $£ 600$. Despite their increasing responsibilities over this decade, the Medical Inspectors were now on a scale lower than that of any other Inspectors in the Board's service. Only three inspectors, plus Buchanan and Thorne, exceeded this scale, and these exceptions were owing only to personal allowances.

${ }_{43}$ MH 19/215. Lingen to Owen, 5 January 1884. The number of annual reports available for distribution thus increased from 170 in 1874 , to 300 in 1876 , to 400 in 1884 .

${ }_{44}$ T.1/8298A/6204/1887. Buchanan to Dilke, 17 November 1883. 
finally obtained temporary relief, in the form of six temporary inspectors. ${ }^{45}$ It was fairly clear, however that '[the Treasury] have only been galvanised into consenting to give temporary help by the fear of cholera finding us unprepared to meet it'.46 Ernest Hart suggested that the Treasury was unwilling to augment the central staff because they believed that the partial payment of Medical Officers of Health salaries from a Parliamentary vote should compensate for having 'nothing more than a skeleton central health department'.47 At all events, in the 14th Annual Report, Buchanan announced again that this temporary help was inadequate and that 'by reason of the urgent pressure of daily duties upon our very limited staff', 48 even cholera inspections were lagging.

In early 1884, Dilke and Owen obtained Treasury approval to an inquiry into the staffing and organization of the Board as a whole. However, this Committee, composed of the retired John Lambert and John T. Hibbert (later Financial Secretary, 1892-95) and George L. Ryder for the Treasury, limited its terms of reference to the Board's clerical staff and secretariat. ${ }^{49}$ The Medical Department was not reviewed in fact, until 1887, when a Committee consisting of George Sclater-Booth, John Lambert, and F. A. 'Court Bergne, ${ }^{50}$ was convened to inquire

into the position and salaries of the Engineering and Medical Inspectors of the Board and the Officers immediately connected with them. ${ }^{\text {s1 }}$

The recommendations of the Committee were disappointing, but hardly surprising. The professional officers requested salary scales comparable to those enjoyed by the General (Poor Law) Inspectors. Lambert disapproved of this on principle, and Sclater-Booth was easily persuaded to distinguish between the General Inspectors, who were assigned as representatives of the Board in distinct districts, and all other Inspectors, who typically worked out of London, whose duties were 'of a special kind', and whose work was 'limited to certain matters within the province of that particular department of the Board to which they were attached.'52 For his part, Bergne was disposed to resist any increased expenditure.

The Committee also reviewed the several applications for staff increases. Hugh Owen's evidence strengthened Buchanan's request for a Second Assistant Medical

45 Dr. De Chaumont; Dr. Davies of Bristol; Dr. Arnold Doyle, C.B.; Mr. Sweeting, from the M.A.B. Western Hospital; Dr. Simpson, well known for his cholera studies at Damietta; and Dr. Bresswell, from the staff of St. Bartholomew's. Lancet, 1885, i, 304, 351.

46 Brit. Med. J., 1885, i, 337.

47 Ibid.

414 th Ann. Rep., M.O.L.G.B.; Brit. Med. J., 1885, i, 90.

$40 \mathrm{~T} .1 / 8113 \mathrm{~B} / 6741 / 1884$. Reorganization of the Clerical Staff, 8 April 1884.

${ }^{50}$ F. A. 'Court Bergne, Principal Clerk of the Treasury, died 15 November 1908. There is no information available about Bergne other than that revealed in Treasury minutes, although evidence suggests that he may have been related to John Bergne, 1817-73, Clerk at the Foreign Office, and the latter's son, Sir John Henry G. Bergne, K.C.B. (1861-1902), also of the Foreign Office. It seems clear, however, that F. A. 'C. Bergne was at this time the senior of the three clerks in the Treasury's Third (Administrative) Division, with jurisdiction over the Home Office, the India Office, the Privy Council, Ireland, Scotland, the Registrar-General, the Stationery Office, the Record Office, the Board of Agriculture, the Board of Trade, the Board of Education, Municipal Corporations, and the Isle of Man. T.172/956. Reorganization of Treasury, Minute, 1904. If only in view of his position, his influence justifies further study.

${ }^{51}$ T.1/8298A/6204/1887. Report of Interdepartmental Committee, 23 March 1887.

52 Ibid., p. 2. 


\section{R. M. MacLeod}

Officer for administrative and advisory work, and the Committee recommended that the new appointment be made from the existing staff of Inspectors. A new Inspector would be needed, they agreed, to fill the latter vacancy, but the appointment of other additional doctors was ruled out completely. Instead of encouraging expansion of the Department's sphere of influence, the Committee recommended shorter inspectors' reports and a greater devolution of work to local sanitary officers. ${ }^{53}$ They also suggested that Local Authorities should be required to pay for the inspection of their own districts, and that central medical and engineering inspectors should be content with their existing, uniform salary scale. ${ }^{54}$

If the Committee dealt heavily with salary and personnel, its attitude towards scientific research was even more restrictive. In January 1887, before the Committee was appointed, the Treasury had reviewed the Board's new estimates in preparation for the 1887-88 budget, and had rejected a request from the Medical Department for a supplementary $£ 100$ to cover urgent experimental studies on infection, water purity and scarlatina under Subhead $\mathbf{R}$ (Auxiliary Scientific Investigations). Such an increase would have brought Subhead $R$ to $£ 2,000$-just the sum which Simon had obtained in his time, and which had since 1876 been reduced to $£ 1,900$ per year. In March, the Treasury replied. Instead of sanctioning the addition, however, they requested the Board to cut its estimate by $£ 800 .{ }^{55}$

A reduced research budget would have crippled current work on the spread of animal disease by milk, a problem which could now be attacked for the first time with bacteriological methods. In January, Buchanan had advised Charles Ritchie, then President, that 'though the Treasury is thus deaf to the representations you have made in the interests of the public health, it may perhaps open its ears to clamour which is certain to come on behalf of an important trade. ${ }^{56}$ But Treasury opinion was hardly in step with either public feeling or the advance of medical knowledge. Buchanan minuted sadly:

However people may be satisfied to disbelieve medical theses, they will not be content that Farmers and Dairymen should forfeit business valued at thousands of pounds. The Government ought to be able to say that investigation of such disease in its veterinary aspects was being undertaken by the Agricultural Department, and that it was in its later relations being studied

63 This, however, would have been quite unrealistic, both because the part-time appointments of most Medical Officers of Health precluded their assuming greater administrative work and because many rural local authorities had made no appointments at all. As late as 1896, only fifteen of the sixty-one County Councils in England (excluding London) had appointed a Medical Officer of Health. Return as to the present Appointments of Medical Officers of Health in England and Wales, 1888. (351), 1xxxvi. 121; Return Showing Salaries and other Remunerations, and the Terms of Appointment of Medical Officers of Health appointed by County Councils in England and Wales, 1896. (202). 1 xxii.645.

54 T.1/8298A/6204/1887. Report of Interdepartmental Committee, 23 March 1887, p. 6. The scale was $£ 500$ three years- $£ 600$, rising by $£ 100$ every five years thereafter to $£ 700$ and $£ 800$.

${ }_{s 5}$ MH 19/217. Jackson to President, L. G. B., 24 March 1887.

so Buchanan added: 'If the grant be not increased, portions of our work will be inconclusive, involving wasteful repetitions and delays. If the grant be curtailed we shall also have mischievous confusion and relaxation in work already organized and in progress. And further, in this event such work as we do for purposes of more general utility must be abandoned, since ... . we must of necessity spend our smaller income for our more selfish purposes.' MH 19/217. Buchanan to President, 26 January 1887. 


\section{The Frustration of State Medicine, 1880-1899}

by your Medical Department, the two acting in concert and having all proper resources at their disposal. The Government will not be able to say so . . . .57

This then was the position in March, when the Interdepartmental Committee met. The Committee conceded that inquiries into the causation of disease were praiseworthy, but that the Government could not encourage 'speculative inquiries . . . which may or may not prove that disease is in some way connected with sanitary administration'. ${ }^{58} \mathrm{~F}$. A. 'C. Bergne stressed this policy in a private letter to William Culley at the Office of Woods:

As regards the Medical Department, there can be no doubt whatever that it has in many cases gone far beyond any reasonable action in the way of so-called "original investigations", and that Dr. Buchanan and some of his staff would, if let alone, and supplied with money, interfere in every department of medicine and surgery; in fact, try to . . . set up a department of State Medicine which would be enormously costly and of which they of course would be the exponents. sp $^{\text {so }}$

Bergne endeavoured to persuade Buchanan 'that it was by no means the business of himself or [his] assistants to start inquiries into subjects which are always under discussion in the medical world', but rather to report simply upon specific subjects referred to him by his superiors. At Bergne's insistence, 'Dr. Buchanan got a pretty sharp lecture from Mr. S.(clater) B.(ooth) as to the necessity of keeping within the proper limits of work.' ${ }^{\text {Bo }}$

In the end, only the repeated intervention of Hugh Owen and Charles Ritchie prevented the Treasury from curtailing expenditure on what Buchanan called 'our most useful work, the only (or almost only) representative of those important laboratories and other institutions that other countries have provided for the study of the sciences of public medicine'. ${ }^{61}$ Viewing his narrow escape, Buchanan gratefully minuted: 'Public Medicine is indebted to Mr. Ritchie for his action in this matter.' ${ }^{62}$ In this and other exchanges with the archexponents of public thrift, Owen gave every evidence of remaining solidly behind his staff. ${ }^{63}$ At the same time, Buchanan

${ }^{57}$ Ibid., Instead, Buchanan foresaw, 'the alternative will be between, on the one hand, a yearly $£ 500$ to be spent in orderly fashion for the study of a group of connected subjects in which these cow maladies would find their place, together with such sum as the Agricultural Department may need for its own explorations; or, on the other hand, an unknown number of thousands to be suddenly expended in hysterical fashion without any valid aid from those who have already made important progress in exploring the difficult questions that are involved.'

${ }^{58}$ T./8298A/6204/1887. Report of Interdepartmental Committee, p. 5.

${ }^{50}$ T.1/8298A/6204/1887. Minute, Bergne (n.d., ca. 20 April). Culley concurred with the Treasury view and sympathized more with the Engineers than with the Medical Inspectors of the Board. 'The increased work and responsibility of the Engineers has been thrust upon them by Acts of Parliament whereas the Medical Department have rather courted work with a view,'as Bergne put it, 'of creating a Department of State Medicine'. Ibid. Culley to Welby, 21 April 1887.

6 T.1/8298A/6204/1887. Bergne to Culley, (n.d.) (20 April). Shortly afterwards, Buchanan declined an invitation to give the first Milroy lecture on State Medicine and Public Health. MSS, Royal College of Physicians, Buchanan to Sir Alfred Pitman, 27 April 1887.

i MH 19/217. Buchanan to Owen and the President, 24 June 1887.

62 MH 19/217. Buchanan to Ritchie and Owen, 5 March 1887.

63 For example, Owen assisted Buchanan in opposing a Treasury minute of 20 December 1888 which threatened, by implementing the Ridley Commission's recommendation, to suspend the granting of additional years' pension allowance to professional officers. Buchanan Office Papers (Ministry of Health), $1888 \mathrm{ff}$. 161-165, Minutes, Buchanan to Owen, and Owen to Buchanan, 22 and 31 January 1889. Because Parliament failed to approve this recommendation, the crisis this suspension would have caused was narrowly averted. This is perhaps remarkable testimony to his political finesse, because Owen consistently enjoyed a reputation with the Treasury as one who was 'usually quite ready to meet our views'. See T.1/8293A/6204/1887. Bergne to Welby, n.d. (22 April) 1887. 


\section{R. M. MacLeod}

gave Owen his loyal support. 'I want to feel', he wrote after one procrustean Estimate exercise, 'that the Board, not the Treasury, is the body to receive explanations from myself.' ${ }^{64}$ In mid-1888, Owen again defended the doctors against a Treasury attempt to require Inspectors to live in the regional districts defined by their vaccination duties, in order to reduce travelling expenses. This policy, however, would certainly have rendered the work of the Department more difficult, not only because there were so few inspectors, but also because the arrangement would have destroyed the capacity of the department to conduct special studies over wide areas. Buchanan's appeal and Owen's subsequent protest eventually forced the Treasury, in the person of Bergne, into a position of grudging acceptance. ${ }^{65}$

But this was slight encouragement to the Medical Officer, whose staff had been reduced after the 1884-85 cholera survey was completed, and whose appeals for increased pay for permanent staff had been categorically rejected. In February 1887, and again in 1889, the medical press scorned official delays which made reports 'invariably out of date', ${ }^{66}$ and in 1888 , Buchanan was again confronted by a Treasury attempt to cut research expenditure to pre-1865 levels. Though the Medical Officer pleaded that 'these researches have had most important bearing on practical sanitation and have without doubt conduced to that great saving of life which has of late years been effected in English communities', ${ }^{67}$ the Treasury remained unmoved. Buchanan minuted angrily:

The Treasury does not seem to know that modern methods of etiological investigation involve biological experiments of more costly character than simple chemical experiments, so that it is only by deferring one and another much needed research ... that the Board have of recent years been able to make their more urgently required etiological investigations while keeping the expenditure of their Scientific Grant within the assigned limits . . . . There is not one of these enquiries which can be intermitted without immediate as well as ultimate loss to the service of the Board and of the public health. ${ }^{88}$

Buchanan continued his efforts, despite mounting frustration, for three more years. When, in 1889, the distribution of Dr. Barry's Sheffield report on smallpox, of immense importance to the vaccination question, was restricted by Treasury price fixing, Buchanan in exasperation offered to contribute $£ 800$ himself towards the costs of publication. ${ }^{69}$ By early 1892 , the situation was thoroughly disheartening. Buchanan, having reached the optional retirement age of sixty, made no attempt to stay at his

64 MH 19/217. Buchanan to Owen, 7 February 1888.

os 'With regard to the Medical Inspectors I am not myself satisfied that some of them might not with advantage live in their districts, but the Local Government Board say that it cannot be done, and I am not sufficiently conversant with the details of the work to be able to contradict the responsible department. On the whole, therefore, I incline to think that we must say that the Local Government Board are responsible for the place of residence of the Medical Inspectors, and, My Lords . . . must leave the Local Government Board to settle the matter . . . ? T.1/8367B/14503/1888. Bergne to Mowatt, 13 September 1881.

${ }_{68}$ Brit. Med. J., 1887, i, 409. The Annual Report for 1889, for instance, was not issued until mid-1891 and Dr. Parsons' report on the influenza epidemic of 1889-90 did not reach the public until 1892fully a year and a half after its conclusions were needed by sanitary administrators. 'Why this portentous delay', commented the Brit. Med. J., 'should recur year after year is quite inexplicable to the public mind. Under the present dilatory method of publication, the value of the reports is sensibly diminished'. Brit. Med. J., 1891, i, 594.

${ }^{67}$ MH 19/217. Buchanan to Öwen, 7 February 1888.

o8 Ibid.

${ }^{\circ} 0$ MH 19/218. Buchanan to President, 22 April 1889. 
post. In a last effort to achieve justice, he applied for a special pension to supplement the moderate amount to which he was entitled, and for the purpose elicited testimony from the leaders of the medical profession. His petitioners included Sir James Paget, President of the Royal College of Physicians, who called Buchanan's annual reports the best published 'in any country in Europe'.

... it proves a rare ability to be so successful as he has been in the use of information derived from a vast number of sources in the selection of fitting subjects of special inquiry, and of the persons most capable of studying them and in advising on the best methods of each inquiry so that all may tend together at the one end-the improvement of the public health. ${ }^{70}$

Hugh Owen, co-operative to the end, approved his effort and Ritchie, himself recently recovered from illness and an operation, submitted to the Treasury a request for a pension equal to two-thirds of the Medical Officer's full salary. ${ }^{71}$ Despite Ritchie's personal intervention, however, on principles of 'sound finance' and with mild surprise at the Medical Officer's bitterness, the Treasury rejected his last request. ${ }^{\mathbf{2}}$ With a K.C.B. and bitter memories, Buchanan left the Local Government Board. ${ }^{73}$

\section{THE INHIBITION OF EXPERTISE, 1892-95}

1. Dr. Thorne-Thorne and the Issues of Office

The early nineties witnessed several new opportunities for enlarging the scope of Medical Department activities to keep pace with the expanding national public health consciousness. The new staff in the senior secretariat appeared receptive to departmental growth ${ }^{74}$ and the appointment of Sir Walter Foster, an experienced medical politician, to the post of Parliamentary Secretary seemed propitious. ${ }^{75}$ But, time and again, vexatious negotiations with the Treasury dampened the doctors' enthusiasm for work, and discouraged the department from acquiring new responsibilities. These symptoms of 'administrative fatigue' were illustrated in the efforts of Dr. Richard Thorne-Thorne, F.R.S., formerly Assistant Medical Officer and now

${ }^{70}$ T.1/8640C/5732/1892. Paget to Ritchie, 13 February 1892. Both Sir William Jenner and Sir Andrew Clark also supported Buchanan's appeal in appreciation of the fact that 'he has contributed largely to our knowledge, he has educated and disciplined a body of workers second to none in the world and he has, helped by the work of Chadwick and Simon, placed England in the position of the authoritative head of all the sanitary work going on in the civilized world'.

71 T.1/8640/5732/1892. Buchanan to Ritchie, 13 June 1892. 'It is to your good offices', he wrote, 'that $I$ look for the arrears of living in reasonable comfort and of doing in a modest fashion my duty for the next few years towards my family, a duty which I could assuredly have discharged if, in giving my services to the public, I had not given them to Her Majesty's Government. You will probably be sensible that it is not to the interests of the Government to exhibit to men of ability desirous of entering the Medical Service of the Government, such an end to their careers as the Treasury is proposing for me-the Principal Medical Officer of your Medical Department'.

${ }_{72}$ The request would have given Buchanan $£ 800$ instead of the $£ 660$ calculated on the basis of twenty-three years service plus ten years credit from his post at the Medical Department of the Privy Council. T.1/8640/5732/1892. Buchanan to Owen, 19 April 1892.

73 He proceeded to become a member of the Royal Commission on Tuberculosis, until his death in 1895 .

74 Of the two Secretaries and two Assistant Secretaries in power in 1874, three were now dead, and one (Lambert) was retired. Brit. Med. J., 1886, i, 456.

${ }_{75}$ Balthazar Walter (later Sir Walter) Foster, first Baron Ilkeston, P.C., M.P. (1840-1913). Active leader in B.M.A. and Birmingham municipal health affairs; representative of medical interests in Parliament, 1885-1910; addressed B.M.A. on public medicine, 1890, 1892 and 1910. Parliamentary Secretary to the L.G.B. 1892-95; rumoured to become President of the L.G.B. in 1905 with return of Liberal Government, but instead was elevated to the peerage. B.M.A. Testimonial, 8 February, 1913, used by courtesy of his nephew, Lt.-Col E. M. Poole, Liss, Hants.; Birmingham Medical Review, 1913, 73, 113-120; Lancet, 1913, i, (8 February). 


\section{R. M. MacLeod}

successor to Buchanan. ${ }^{76}$ The British Medical Journal, acknowledging his 'unrivalled acquaintance with administrative detail and ready fact', welcomed his appointment as maintaining 'the continuity of the policy pursued by the Medical Department'."7

There was, in fact, a continuity of crisis. Thorne-Thorne was confronted immediately with the prospect of cholera, then spreading westward from the Red Sea, and threatening to reappear in the British Isles. The familiar 'harbinger of reform' offered Thorne-Thorne a precious opportunity for departmental expansion. The fear of cholera after a decade's reprieve clearly riveted public attention to the need for research into the prevention of disease. 'In spite of all the vaunted science of the ninteenth century', confessed The Times, 'we are entirely in the dark as to the origin, the nature and the cause of the destructive malady'. ${ }^{78}$ Because confident assertions of immunity did not suffice to dispel rumour and panic, the Treasury could hardly resist public pressure for further medical research and for a fresh survey of local and port sanitary facilities.

In the autumn of 1891, Thorne-Thorne, influenced strongly by these exigencies, drafted a comprehensive proposal for revitalizing central health administration. Arrears of work had again accumulated, both in Whitehall and in the provinces. As a result of Treasury parsimony in the appointment of staff, over 200 correspondence files directed to the Medical Officer had not received attention; the annual report for 1891 was months behind schedule, and the proposed research on influenza for which the department had wrung a $£ 1,000$ grant in March was not even planned..$^{79}$ In addition, two Royal Commissions were demanding testimony from the Medical Officer, despite his insistence that he had no 'time even to read evidence already given on the subjects in question' ${ }^{80}$

To cope with office work in London, Thorne-Thorne requested only a Second Division clerk. But work in the provinces required far greater assistance. Over 100 important local inquiries, some delayed over a year since secretarial sanction, had not been initiated. District vaccination inspection, an index of the Department's inspectorial efficiency, had fallen vastly in arrears and the number of unvaccinated

70 Richard Thorne-Thorne (1841-1899). Early education in Prussia and France; M.B., University College, London; M.D., F.R.C.P., F.R.C.S., F.R.S.; Physician to London Fever Hospital and Royal Hospital for Diseases of the Chest; appointed permanent Medical Inspector, Medical Department of the Privy Council, 1870; Assistant Medical Officer, 1883; Medical Officer, 1892-99; active in Epidemiological Society; British representative to International Sanitary Conference in Rome, 1885, and to Conferences in Dresden, Paris and Venice in 1892, 1893, 1894, and 1897; K.C.B., 1897. Brit. med. J., 1883, i, 922; 1892, i, 982; 1899, if, 1772-73; Lancet, 1899, ii, 1762-66; Public Health, $1891-92 ; 4,360 ; 1900,12,245-46$, Local Government Chronicle, 1899, p. 1201.

"7 The British Medical Journal commented, "upon the cordial character of the intimate relations between the Medical and other departments of the Board the success of our national health and administration depend to a very large extent and these will be fully maintained by the new Medical Officer, who brings to his duties ripe experience in administrative work and a wide acquaintance of the scientific aspects of preventive medicine.' Brit. Med. J., 1892, i, 982. Dr. William H. Power was made Assistant Medical Officer and Dr. H. F. Parsons was promoted to Power's position. The vacancy in the Inspectorate was filled by Dr. H. J. Bulstrode, Honorary Secretary to the Epidemiological Society, Senior Assistant Medical Officer to the Metropolitan Asylums Board Hospital, and Examiner in Hygiene to the Science and Art Department. Lancet, 1892, ii, 263.

${ }^{78}$ The Times, 15 January 1892.

70 T.1/8635B/1754, 3561/1892. Provis to Secretary, 30 January 1891, Treasury to Secretary, Local Government Board, 5 January 1892; Owen to Secretary, Treasury, 29 February 1892; Secretary, Treasury to Secretary, Local Government Board, 8 March 1892.

${ }^{80}$ T.1/8687A/17448/1892, Owen to Secretary, Treasury, 17 November 1892. 


\section{The Frustration of State Medicine, 1880-1899}

children was steadily rising. As many as 686 Vaccination Districts in fourteen counties had not been inspected in over two years. A cholera epidemic could hardly be contemplated calmly by the Medical Department in its current condition. Accordingly, Thorne-Thorne requested two permanent Medical Inspectors, one to act as a temporary Assistant Medical Officer, and four temporary Medical Inspectors for one year to clear up arrears and expedite the cholera survey. ${ }^{81}$

In recognition of the Department's chronic overwork, Thorne-Thorne also requested an increase in salaries for the Medical Officer and the Senior Assistant Medical Officer. In so doing, he brought to the surface a latent discontent smouldering within the Department since 1876. In Simon's time, the pay of the Medical Officer, and thus, to an extent, his status in the Local Government Board hierarchy, had been the subject of continuous debate. Owing largely to Lambert's desire to abolish the 'untidy, exceptional and peculiar' secretariat of the Medical Officer, and to 'facilitate improvements in the organization of that branch of the Department of the Local Government Board to which Mr. Simon belongs and at the same time effect a saving in the charge for the salaries of the office, ${ }^{82}$ the salary of Edward Seaton, Simon's successor, had been reduced from $£ 2,000$ to $£ 1,300 .{ }^{83}$ In 1880, on Buchanan's appointment, the salary of the post was further reduced to $£ 1,200$, and in April 1892, when Buchanan resigned, his successor was offered only $£ 1,000 .^{84}$ At first, Thorne-Thorne refused to be promoted under conditions which involved a 'further lowering of the status of the office,' and was persuaded to accept the post only after Charles Ritchie promised to appeal again to the Treasury on his behalf. ${ }^{85}$ In 1892, H. H. Fowler took up Ritchie's promise and requested Treasury reconsideration on grounds that Thorne-Thorne's personal presence at the Sanitary Conferences of Venice and Paris had been instrumental in creating a 'Common Market' agreement about quarantine regulations affecting British ships in European ports. ${ }^{86}$ To appoint him at a reduced salary would have been an act of injustice.

William Power, the new Assistant Medical Officer, provided another case of relative deprivation. While most Medical Inspectors were paid on a scale reaching $£ 800$ after thirteen years service, Power, by virtue of his early arrival at the Medical Department, had reached that level after seventeen and a half years in 1890 . The $£ 100$ in addition to his maximum salary to which he was entitled as Assistant Medical

81 Ibid.

${ }_{82}$ MH 19/211. Lambert to Treasury, 23 March 1876. Lambert assured the Treasury that when Seaton took up his new post, "the office contemplated by this appointment will be quite different from that held by Mr. Simon ... both as regards the mode of appointment and the duties to be discharged'. By terminating Simon's joint appointment under the Public Health Act of 1858, Lambert was able to argue successfully for a reduction in Seaton's new salary.

83 MH 19/211. Lambert to Treasury, 6 April 1876.

84 T.1/8687A/17448/1892. Fowler to Secretary, Treasury, 17 November 1892.

85 'I have communicated with the Chancellor of the Exchequer expressing my dissatisfaction with this decision and asking for its reconsideration .... I am unable to carry the matter further, but had I remained here I should certainly have pressed it'. MH19/219. Minute, Ritchie, 3 August 1892.Thorne later recalled: 'He pressed me a great deal, and others pressed me, and after about ten days, I felt that I had been so very much pressed that I would accept, Mr. Ritchie saying that he would do his best at least to save that $£ 100$, but that he could not. The Treasury refused him, I think, three times'. Report of the Departmental Committee on the Clerical Staff and Secretariat of the Local Government Board, 1898, xl, [C.8731]. Mins. Evid., Q.1157.

${ }_{86}$ Medical Department Papers (Ministry of Health), 1885, f.93, 100-101, Thorne-Thorne to Buchanan, Sir Charles Dilke, and Sir J. S. Lumley, 8-19 June 1885. 


\section{R. M. MacLeod}

Officer did not relieve his sense of injury. Like Thorne-Thorne, he refused at first to accept promotion to a post of greater responsibility, and relented only when given permission to submit a memorandum protesting against the Government's treatment of medical officers. ${ }^{87}$

In July 1892, Fowler submitted Thorne-Thorne's proposals and Power's memorandum to the Treasury. From the Treasury's point of view, however, the doctors were making excessive demands based on false assumptions. Thus, F. A. 'C. Bergne minuted:

It was made clear to the Committee [of 1887] ${ }^{88}$ that the Medical Officers could relieve themselves by ceasing to invent all sorts of recondite investigations which they had been in the habit of undertaking without any authority from the Board. Lord Basing [Sclater Booth] told us that the practice was wholly wrong and thus the best way of stopping it was to let the Inspectors have their time well filled up by the work they were ordered to do. ${ }^{89}$

In a word, if the doctors insisted on doing more than they should, the Treasury should hardly be made to pay for the consequences. Bergne, therefore, rejected Fowler's request. On the same grounds, Bergne refused the appointment of any additional permanent Inspectors. Four additional temporary Inspectors were sanctioned, but only for the duration of the cholera crisis. ${ }^{90}$

At this juncture Fowler proved an advocate for his doctors. He appealed personally to John Hibbert (Financial Secretary) and Francis Mowatt (Permanent Secretary) in Hibbert's room at the Treasury. The President's influence prevailed. For the first time in some years, the Medical Department was brought to the attention of the permanent head of the Treasury, who under the circumstances gave way. After the meeting, Mowatt reversed Bergne's decision:

I sympathise with Mr. Bergne's objections to re-opening the question of staff and salary which was settled so recently as 1887 on the recommendations of an experienced and competent committee, but it was not possible in $\mathbf{1 8 8 7}$ to foresee the growth of public opinion in the last five years as to the extent to which the government should intervene in all questions connected with public health. This growth is not I think at all over-presented by the increases now asked for. ${ }^{91}$

According to Thorne-Thorne, 'the moment Mr. Fowler came in . . . the Treasury did it, and sent me a most complimentary letter' ${ }^{92}$ Mowatt sanctioned not only the four

${ }^{87}$ T.1/8660C/12060/1892. Memorandum, Power to President, 16 July 1892. Power insisted that the 'ever widening functions of the department and of its medical officer in chief' required him to 'study and master all the important questions that engage, and the multifarious business which occupies the attention of his departmental chief while at the same time, he duly performs the sufficiently numerous and by no means trivial duties that appertain more particularly to his own office.'

${ }^{88}$ Bergne had commented in July that, "there is little use in taking up many days time of public officers in revising a department and then to ignore the proposals made and accepted, on the first chance to bring them into effect. In any event a pay rise would disrupt the uniformity of scales settled for both the Medical and Engineering Inspectors in 1887.' T.1/8660/11650/1892. Owen to Secretary, Treasury, 13 July 1892. Finally, Bergne also pointed out, that these scales were not settled by the Treasury but by John Lambert and Sclater Booth on behalf of the L.G.B. itself. T.1/8687A/17449/1892. Minute, Bergne to Mowatt, 21 November 1892.

${ }_{89}$ T.1/8660 C/12060/1892. Note in margin, 16 July 1892.

o0 T.1/8687A/17449/1892. Minute, Mowatt to Hibbert, 7 December 1892.

01 Mowatt added significantly. "As regards salaries, we must not forget that the salaries fixed by the County Councils for Medical Officers compare favourably with those received in the service of the State and that they naturally react somewhat upon those of the Local Government Board Inspectors whose duties bring them into frequent contact with the County Officers.' T.1/8687 A/17449/1892. Mowatt to Hibbert, 7 December 1872.

${ }_{22}$ Report of the Departmental Committee, Mins. Evid. Q.1157. The British Medical Journal, perhaps self-consciously, gave credit for this achievement to Sir Walter Foster, as the power behind Fowler. Brit. Med. J., 1892, ii, 1357. 


\section{The Frustration of State Medicine, 1880-1899}

temporary Inspectors, but two permanent Inspectors as well, and also confirmed the importance of the Medical Officer's role in international health proceedings. ${ }^{93}$ The permanent Medical Staff was thus raised to fourteen. ${ }^{24}$ Nothing was done on the question of salary.

Throughout these years, such negotiations characterised the Department's dilemma. Although Hugh Owen continued to co-operate and Foster's presence in Parliament brought publicity to the doctors' plight, the Department's relations with the Treasury clerks, and particularly with Bergne, remained tense and untrusting. Small, picayune details exacerbated this tension. When, for instance, Owen wished the 'writer' of the Vaccine Branch to have an established position as 'Assistant Clerk', Bergne impulsively dismissed the proposal:

I have little doubt that ... the Medical Officer invents useless and lengthy returns simply because there is a competent man who is willing to do them in overtime, and this work is no proper part of the Vaccine Department.95

It was ironical that, in spite of these obstructions, the small requests of the Medical Department, like those of most circumspect government agencies, were eventually granted. ${ }^{96}$ But sanction was given only when restrictionist argument failed; cordial acquiescence was rare.

A final example of this estrangement is instructive. In December 1895, the Medical Department applied for permission to extend the appointment of one of the four temporary Inspectors authorised in 1893. The Department had released two of the four men the previous year, and wanted modestly to complete the work left by the Cholera Survey. Thomas (later Sir Thomas) Heath (a new junior clerk at the Treasury, and later Permanent Secretary) minuted to Bergne that it was obviously 'difficult for the Treasury to object to the recommendations of the Local Government Board affecting Public Health', ${ }^{97}$ and indicated that further consultation was necessary. Bergne, with myopic self-assurance, denied the request outright. ${ }^{98}$ In this case, Robert Hanbury, the new Financial Secretary, reversed Bergne's impressively shortsighted decision, and granted the request, 'assuming the Local Government Board are

a T.1/8687A/17449/1897. Mowatt to Secretary, Local Government Board, 6 December 1892.

* One Medical Officer, two Assistant Medical Officers, and eleven Medical Inspectors. Dr. Barry, as Senior Medical Inspector, was taken into the office staff to share administrative work. Buchanan Office Papers (Ministry of Health), 1892, f.1, 14 December 1892.

os T.1/8859/7019/1894. Minute, Bergne to Mowatt, 19 May 1892. The work which had 'no proper part' in the Department included assisting the Director of the National Vaccine Establishment in keeping registers of doctors who failed to report results of calf lymph vaccinations; examining all requests for lymph, keeping regular files of the National Vaccine Establishment; sending out circulars and lymph and assisting Medical staff in the preparation of weekly notifications of infectious diseases in London; listing smallpox cases and admissions to hospitals in London, and making fortnightly returns of infectious disease admissions and quarterly mortality statistics of all notifiable diseases in provincial towns. See T.1/8859/8902/1894.

* See T.1/8859/13950/1894. B. Mallet to Ryder, 19 September 1894.

${ }^{97}$ T.1/8985B/1765/1895. Minute, Heath to Bergne, 14 December 1895. Thomas Heath (18611940), entered the Civil Service in 1884, became assistant secretary in 1907 and Joint Permanent Secretary (administration) in 1913. K.C.B., 1909. Comptroller-General, National Debt. Office, $1919-26$.

o8 'I cannot say that I think that any urgent need is proved for retaining the services of even one temporary inspector for as cholera is not yet within 1,000 miles or so . . it is not exactly evident what the extra man has to do.' Ibid., Bergne, 14 December 1895. 


\section{R. M. MacLeod}

satisfied that further work of this kind remains to be done'. ${ }^{90}$ The whole matter was quite incidental, but instances of this kind were commonplace, and their cumulative effects were devastating.

\section{The Unification of Medical Services: A Missed Opportunity}

The late nineties found the Medical Department philosophically frustrated and physically exhausted. In spite of Owen's best efforts, continuing Treasury restrictionism bore heavily on the Medical Officer and the senior medical staff, who were most responsible for the development of British health administration. Such was the Department's condition that opportunities for extending its work and for making it a more effective instrument were either overlooked or purposely neglected. This tendency is illustrated in the lengthy discussions between the Medical Department and the Medical Inspectors of the Poor Law Division concerning the central organization of public health.

In their report of 1871, the Royal Sanitary Commission had stressed the desirability of avoiding 'parallel inspectorates of Sanitary and Poor Law Administration under the same chief Minister, not only on the ground of waste of powers but still more of probable conflict. ${ }^{100}$ As Royston Lambert has shown, a parallel structure did emerge, not only because of conflict between Simon and John Lambert, but also because of hostility between Simon and Dr. Edward Smith, the incumbent Medical Inspector for Poor Law Purposes, who had been transferred to the Local Government Board with the Poor Law staff. In this case, Simon was as culpable as either Lambert or Smith. ${ }^{101}$ Lambert, particularly, had every reason to integrate administratively the two departments. In a memorandum on office organization in 1873, Lambert expressed the hope that 'Poor Law medical questions should . . . be remitted to the Medical Officer of the Board'.

I observe that Mr. Simon treats this business as foreign to that which should devolve upon him, but if there is a medical Department of the Board it appears to me to follow that the Department should advise the Board in relation to all questions on which Medical assistance is required. ${ }^{102}$

If this were not done, Lambert felt, the Local Government Board would be advised by two medical officers: by one when dealing with Boards of Guardians as providers of medical care for the poor, and by another when dealing with Guardians as rural sanitary authorities. ${ }^{103}$

At the time, Simon resisted this development, claiming that the business of sanitation and technical public health was so overwhelming that 'for a long time to come the Medical Officer of the Board must be quite unable to give much personal attention

\footnotetext{
99 T.1/8985B/1765/1895. Hanbury minute, 15 December 1895. Robert Hanbury (1845-1903), Conservative M.P., Privy Councillor and Financial Secretary to the Treasury, 1895-1900; joined Cabinet as President of the Board of Agriculture, 1900.

100 Second Report, Royal Sanitary Commission, 1871, [C.281]. xxxv. p. 33.

101 R. J. Lambert, Sir John Simon, p. 557-8. Simon's own personal obsession with pride of place was evident in the later chapters of his English Sanitary Institutions, and has been commented upon by Royston Lambert. Evidence of John Lambert's ability to work more easily with 'experts' who demanded less autonomous authority can be found in the case of Robert Angus Smith and the Alkali Inspectors. See R. MacLeod 'The Emergence of the Civil Scientist: the Aklali Acts Administration, 1863-1884, Victorian Studies, 1965, 9, 85-112.

102 Reports on Medical Department Staff, (Ministry of Health), Memorandum, 'Office Administration', John Lambert, 10 January 1873.

103 Ibid.
} 
to Poor Law Medical questions' ${ }^{104}$ Moreover, Simon's personal contest with Lambert had just begun, and the Medical Officer was anxious to keep his authority intact and his jurisdiction unquestioned. No doubt Simon was irritated by the consequence of this bifurcated policy, according to which systematic inspection of the provinces was given to the non-medical General (Poor Law) Inspectors of the Board rather than to Medical Inspectors responsible to the Medical Officer. Nevertheless, he insisted on maintaining a distinct and separate 'health department', and set himself against Lambert's plan to unite both activities into an administrative whole. ${ }^{105}$ When pressed to take over central medical supervision of workhouses, Simon insisted on inspection by his own Medical Inspectors (as distinguished from the District Medical Inspectors). But when the necessary increase in staff was not forthcoming, the whole question lapsed. Dr. J. Mouat, an ageing poor law doctor, was later appointed by James Stansfield as Medical Inspector for Poor Law Purposes, ${ }^{106}$ and the separation between the two areas became complete. Dr. Mouat accepted the appointment 'on the distinct understanding' that he would not be attached to the Medical Department, ${ }^{107}$ and that he would exercise supervision only over poor law medical work in the provinces, much as Dr. J. H. Bridges did as Medical Inspector for Poor Law Purposes in London. ${ }^{108}$ In 1887, the Interdepartmental Committee recommended that all Medical Inspectors be placed under one chief. ${ }^{109}$ An opportunity for this occurred in 1888, with Mouat's retirement. At that time, however, Hugh Owen decided that 'the change contemplated should not be carried into effect' until Dr. Bridges retired.110 But Owen's recommendation that Mouat's successor be temporarily appointed as a General Inspector for three years was resisted by Bergne, who found that the 'present proposal tends to continue indefinitely a system which has been condemned'.111 Bergne also questioned whether Dr. Bridge's retirement was a necessary prerequisite

\footnotetext{
104 Ibid.

${ }^{105}$ This policy often led Simon to contradict his own ideas for better health inspection. In November 1873, Simon suggested that the Poor Law workhouses ought to be under 'systematic medical visitation', and that it would be appropriate to assign the Poor Law Medical Inspector to the Medical Department for this purpose. Ultimately the area of inspection might be extended to outdoor relief as well. James Stansfeld, while doubtful that workhouses could be medically inspected at that stage, felt that the duty should be assigned, when practicable, to 'the Medical Inspector who usually visits the district within which each workhouse is situated'. At this prospect of inspection by District (Poor Law) Medical Officers, Simon's enthusiasm waned. Reports on Medical Department Staff, 1873, 'Office Organization (Medical Department)', Simon to Lambert, 15 November, Lambert to Simon, 19 November 1873 , 43164/73. Stansfeld's notes on the discussion of 26 May, 1873, Simon to Lambert, 24 November 1873.

${ }_{106}$ At the time of Simon's resignation, Lambert hoped that Mouat's successors 'would occupy the same relation to the head of the Medical Department as the other Medical Inspectors'. MH 19/211. Lambert to Treasury, 6 April 1876. Ralph Lingen also wanted the L.G.B. to effect such a change immediately: 'The continuance of an anomaly of this kind is a constant source of danger to the complete consolidation of their medical staff ... the reason for it has ceased with the state of transition out of which it grew'. MH 19/211. Lingen to Lambert, 26 April 1876.

${ }_{107}$ MH 29/211. Lambert to Lingen, 9 May 1876. This division of responsibility gave additional men for poor law inspectors on occasions when General Inspectors were ill or absent. Ibid., margin note by Sclater-Booth.

${ }_{108}$ Dr. John Henry Bridges (1832-1906); Fellow of Oriel College, Oxford, 1855-60; M.R.C.S., 1860; F.R.C.S., 1866; physician, Bradford Infirmary, 1861-69; Medical Inspector, L.G.B., 1869-92; noted Positivist and translator of Comte.

100 Interdepartmental Committee, 1887, p. 10. Culley in fact had recommended to Welby that Mouat be retired, thus 'making room for the additional Medical Inspectors on the ordinary staff of Medical Inspectors'. See T.1/8289A/6204/1887, Culley to Welby, 21 April 1887. The two Poor Law Doctors were christened 'anomalous inspectors'. Ibid., William Jackson to Bergne, 30 January 1889.

110 T.1/8394A/2934/1889. Owen to Secretary, Treasury, 28 January 1889.

111 T.1/8394A/2934/1889. Bergne to Secretary, Local Government Board, 2 February 1889.
} 


\section{R. M. MacLeod}

for the proposed consolidation, and why there should be an 'appointment of a General Inspector with the duties (medical) referred to, instead of the appointment of a medical inspector'.112 However, he finally granted sanction for a temporary Inspector at $£ 600 .{ }^{113}$ In November 1892, when Dr. Bridges retired, Owen acknowledged Lambert's conception of a unified Medical Inspectorate, but decided that the effort involved was too great.

The Board are fully satisfied that the present arrangements have had very beneficial results as regards the administration of the Poor Law, whilst at the same time, they have been entirely satisfactory to the Department and the Officers concerned. ${ }^{114}$

This decision was not, however, made by the secretariat alone. Evidence now suggests that Dr. Thorne-Thorne, suffering acutely from overwork, actively discouraged Owen from acting on Lambert's suggestion. When conferring with Owen and Knollys (Assistant Secretary of the Poor Law Division), the Medical Officer agreed to a provisional arrangement in case it should be decided that the Poor Law Medical work of the Board is to be placed under the Medical Department' ${ }^{115}$ But Thorne-Thorne insisted that the mere transfer of Poor Law work and staff would solve none of the real problems besetting the Board. Advantages in theory would be offset by difficulties in practice, and the transfer would beg the most serious questions affecting the Department.

Every year the amount and responsibility of the work devolving upon the Medical Officer and Assistant Medical Officers steadily increases; that increase has been greater than ever in recent years; and it is useless to pretend that we can properly undertake further work for the Board unless means are provided for affording the Department some substantial assistance. 116

From his semi-official correspondence, it is clear that Thorne-Thorne's anxiety was reaching a critical, almost neurotic stage, which his memorandum to Owen betrayed:

Quite apart from the increase of work which has been cast upon the staff Officers in the Medical Department during the recent cholera emergency and from that which is in prospect for them in view of the possible recandescence of cholera next year, the duties attaching to the Department have become so heavy that I do not believe the present strain can possibly be maintained without grave sacrifice of health and almost certain risk of breakdown. ${ }^{117}$

112 T.1/8394A/2934/1889. Minute, Bergne, 14 February 1889.

113 Subject to the condition that the 'Local Government Board is to be at liberty to place this office under the Medical Department at any future time', and on the understanding that 'it is the intention of the Local Government Board to do this on a vacancy occurring in the post held by Dr. Bridges if not earlier'. Ibid., Minute, Jackson, 19 February 1889; Bergne to Jackson, 14 February 1889. Dr. (later Sir Arthur) Downes was appointed temporary Medical Inspector.

${ }_{114}$ T.1/8687A/17448/1892. Owen to Secretary, Treasury, 7 November 1892.

$115 \mathrm{Dr}$. Arthur Newsholme, Views of the Local Government Board on Medical Inspection, (Ministry of Health), p. 2. The provisional plan required Downes to become jointly Medical Inspector for Poor Law purposes in the Metropolis and Assistant Medical Officer for Poor Law purposes in the Medical Department. It required a new Medical Inspector and provided that the Medical Inspector for provincial Poor Law work would report directly to the Medical Officer. Also, it provided that the Medical Officer would have power to propose enquiries into the medical aspects of Poor Law administration. Arthur Newsholme later collected these, and below-mentioned documents, and bound them together for reference during his tenure as Medical Officer, 1908-1918. I shall deal in a subsequent paper with the relevance of these documents and Newsholme's attempted consolidation of the Medical Inspectorates following the Report of the Royal Commission on the Poor Laws.

$116 \mathrm{Ibid}$., quoting a letter from Thorne-Thorne to Owen, 7 November 1892.

117 'Both Mr. Power and I', he continued, 'have arrears of work which we see no present prospect of overtaking and this although we both regularly take home work at night. And apart from ever 


\section{The Frustration of State Medicine, 1880-1899}

Thorne-Thorne asked that no additional work of any kind be placed upon his Department before the Treasury conceded additional staff and increased salaries for Mr. Power and himself. ${ }^{118}$ Owen agreed, and to the Treasury wrote:

The Medical Officer of the Board and the General Inspectors are very adverse to the change and the Board are clearly of opinion that it would be attended with many administrative difficulties. The Medical Officer and the Assistant Medical Officer are without any experience in connection with Poor Law Institutions and administration, and to impose upon them the supervision of this class of work would entail a considerable demand on the time and consideration of the Medical Department which it is most important should be given to the questions affecting the health of the country. ${ }^{110}$

To propitiate the Treasury, Owen proposed to replace Bridges by Dr. (later Sir Arthur) Downes ${ }^{120}$ at a salary on the Medical Inspectors' scale rather than on the higher General Inspectors' scale. The Treasury did not comprehend that Owen's letter arose from overwork and underpay, and Bergne irrelevantly commented on the Board's 'mistake'. ${ }^{121}$ The Treasury ultimately agreed, however, to sanction the request. Dr. Downes was promoted and given a clerk to assist him. ${ }^{122}$ The opportunity to

increasing current work, special questions involving much labour and time are always arising. Thus, at the present time two Royal Commissions have intimated to me that they desire us to give evidence before them. I have not had time to make any preparations for this, nor have I even unpacked the voluminous papers submitted to me several months ago by one of the Commissions for perusal and study before giving evidence. Mr. Power and I (notably Mr. Power) have for years past foregone much of our allotted period of leave of absence, and if we both took such leave as we are entitled to for this one year alone, one or other of us would be absent until about mid-January next.' The two Royal Commissions were those on Vaccination and Tuberculosis. Ibid., 'Views of the Local Government Board on Medical Inspection' (Ministry of Health). Thorne-Thorne to Owen, 7 November 1892.

118 'In view of our long service and of the heavy responsibilities attaching to our work and in view of the fact that heretofore almost every substantial increase of duty imposed upon, or willingly assumed by us, has been accompanied by a lowering of the status of our office in the eyes of our colleagues and the Public Service, I venture to urge, and strongly urge, that no fresh imposition of duty should be cast upon us until that which in my case at least was admitted by the late President to be "a wrong" has been remedied.' Ibid., Thorne-Thorne to Owen, 3 November 1892.

${ }_{119} \mathrm{~T} .1 / 8687 \mathrm{~A} / 17448 / 1892$. Owen to Secretary, Treasury, 17 November 1892 . Owen's letter was a faithful reproduction of Thorne-Thorne's memorandum, which read: 'I and the staff on the Medical Department never engaged ourselves for such work; all the staff whose opinions I know are very much adverse to undertaking the duties involved; both Mr. Power and I are at present unacquainted with the subject and we could not properly advise on it except at the cost of an amount of thought, time and study which we do not feel ourselves able to give to it and apart from this, I do not see how the duties involved can be sufficiently performed on such terms as those suggested .... ThorneThorne to Owen and President, 3 November 1892.

${ }_{120}$ Sir Arthur Downes (1851-1938), University College, London; M.B., C.M., M.D.; Aberdeen, D.P.H., Camb; M.O.H. for Shropshire and Essex, 1876-89; Medical Inspector, L.G.B., 1889-1919; member of many Royal Commissions and Departmental Committees on health and social welfare; published papers in the Proceedings of the Royal Society on the destructive effects of light on bacteria.

121 'Instead of doing what the Commissioners [of 1887] proposed, viz., to make the new men part of the General Medical Staff, the Local Government Board propose to continue the separate offices. I think this is a mistake because if the two Poor Law Inspectors are fully employed it will not hurt the Medical Department to bear them on its staff, and if they are not (as Sir John Lambert was convinced that at least Dr. Mouat was not), their spare time is wasted instead of being used for general purposes.' T.1/8678A/17449/1892. Bergne to Mowatt, 21 November 1892. Mowatt, after consultation with Fowler and Hibbert deferred to the 'very strong opinion entertained by the Board that the time has now arrived at which the proposal of the Committee of 1887 would with advantage be carried by making these two offices part of the staff of Inspectors under the direct supervision of the chief Medical Officer'. T.1/8678A/17449/1892. Mowatt to Secretary, Local Government Board, 6 December 1892.

${ }_{182} \mathrm{~T} .1 / 9225 \mathrm{~A} / 188 / 1898$. H. W. Todd, who began as clerk to Downes in 1890 was soon involved in the doctor's fresh inquiries into workhouse dietaries, collecting returns from Metropolitan separate and district schools, and certified homes and admission returns from the Metropolitan Asylums Board hospitals. The altered character of Poor Law medical administration after Bridges's retirement and Downes' appointment, and the personal factors of administration implicitly involved, 


\section{R. M. MacLeod}

coordinate efficiently the prevention and treatment of disease on a national scale was thus postponed indefinitely.

\section{PUBlic SCRUTINY AND DEMANDS FOR Change}

These, then, were the circumstances which confronted the Committee of 1898, and which were made public knowledge by parliamentary report. ${ }^{123}$ Between 1872 and 1898, Medical Inspectors of the Board had accomplished only 1,326 routine sanitary inspections, or an average of less than one inspection per sanitary authority in twentysix years. ${ }^{124}$ The ten Inspectors involved in the cholera survey of 1885-86 had completed about 570 inspections and the twelve Inspectors of the Inland Sanitary Survey of 1893-95, about 260 , but these only illuminated areas which required closer study. ${ }^{125}$ Private surveys of the public health revealed vast areas of neglect, particularly in rural communities. Moreover, Thorne-Thorne's attempts to devolve more correspondence upon the establishment, in order to release his Inspectors for more significant work, ${ }^{126}$ often had the unhappy effect of depriving local authorities of badly needed expert advice and precise technical instruction.

In his evidence before the Committee, Thorne-Thorne revealed how his own position had deteriorated. Because of overwork, he had actually opposed British participation in the Paris and Vienna International Health Conferences of 1892 and 1894 and agreed to represent Britain at the conferences only because if he had not, the Colonial Office and Foreign Office would have appointed their own Medical Officers, and in so doing, demolish what uniformity and order did exist in British health administration. The nation and the Treasury, Thorne-Thorne said, had proved altogether unappreciative of his efforts. The Medical Officer 'occupied the lowest status of anyone in the whole public service who has any corresponding position.' ${ }^{127}$ Questioned about alleged departmental inefficiency, he frankly replied, 'when

would surely repay further study. To the vacant post of Poor Law Inspector for the provinces was appointed Andrew Fuller, L.R.C.P.(Ed).), M.R.C.S.(Ed.), of Rugbrooke, Northamptonshire; formerly Senior Clinical Prizeman, Qucen's College, Birmingham, who had 'somewhat lengthened experience of Poor Law Medical Service', Lancet, 1893 i, 259. He had been Medical Officer and Public Vaccinator to the Rugbrooke District of the Northampton Union, Brit. med. J., 1893, 1, 193.

123 First Report of the Committee appointed to Inquire into the Sufficiency of the Clerical Staff and Secretariat of the Local Government Board, having regard to the duties devolving upon the Board and with the Existing Divisions of Work, the Salaries, the Officers, and the Organisation of the Department generally, and to recommend what changes be made in the Existing Arrangements, 1898, xl, [c.8731]. 429, (hereafter abbreviated First Report). This committee was composed of J. T. Hibbert (formerly Financial Secretary), Francis Mowatt (Permanent Secretary) and H. W. Primrose (clerk) on behalf of the Treasury, and T. W. Russell (formerly Parliamentary Secretary) on behalf of the Local Government Board.

124 Calculated from Medical Inspectors Reports, published and unpublished, in the possession of the Ministry of Health.

125 'Report on Cholera', 1885. [c.4873], and Ann. Rep. M.O. L.G.B., 1886. [c.5171]. Ann. Rep. M.O. L.G.B., 1897. [c.8215].

${ }_{126}$ For example, he sought permission for Medical Inspectors to send files directly to K-2 division, rather than through the Medical Officer. Medical Department Papers (Ministry of Health), 1895, f.2; Thorne-Thorne memorandum, 2 April 1895. Work relating to the formation of Joint Hospital Boards, the inspection of disinfecting apparatus and mortuaries was transferred from $K .1$ division (Sanitary Administration), to K. 2 division (Public Health), and from the Engineers to the Medical Inspectors. Medical Department Papers (Ministry of Health), 1894, ff. 162-8. Correspondence among Owen, Major Tullich, and Thorne-Thorne, 5-20 March 1894.

127 Commissioners of Lunacy, he added, "who have simply to go and visit a few lunatics whom they have not even the responsibility to declare lunatics, all get $£ 1,500^{\prime}$. First Report, Mins. Evid., Q. 1196. 
we cannot do work we do not do it, and heaps of things that ought to be inquired into are never put forward to be inquired into at all.'128 If local authorities chose to be negligent, the Medical Department was unable to avert local disaster or to bring government pressure to bear. ${ }^{129}$

The alternative, in Thorne-Thorne's mind, to more pay and higher status was simply less work. Since 'every increase of work in the Medical Department has been associated with a diminution in the status and salary of those at the head of it', he pointed out to the Committee, "it is very difficult for me to continue to ask for increase of staff'. He therefore suggested a moratorium on state medicine.

I have told the President and Mr. Russell that I shall never ask for an increase of inspectors because the increase by even a single inspector means a considerable increase of the work of the Medical Officer and the Assistant Medical Officer. ${ }^{130}$

This Gilbertian parody of government does not seem to have shocked the Committee, but its significance for the health-consciousness of Local Authorities, for the study of infectious diseases, and for public vaccination, not to mention medical research, or any potential policy for the sick poor, could scarcely be more profound. The proud creation of Simon, a Medical Department to lead the nation towards better health, was visibly shaken when Thorne-Thorne confessed his failure to reach these goals and his unwillingness to try: 'So far as an extension of work is concerned, I hope you will understand that it is not I who have suggested any extension of work, it is the Board that have tried to get $m e$ to agree to it.'131 His reply alone deflated the myth that the Medical Department had been martyred at the hands of the Board's lay administrators. Blame lay more with the Treasury, and perhaps, paradoxically with the attitude of Thorne-Thorne himself.

The recommendations of the Committee were, under the circumstances, the least that could have been expected. The Medical Officer was advanced to a scale of $£ 1,200-£ 1,500$, with Thorne-Thorne proceeding immediately to the maximum. ${ }^{132}$ The Second Assistant Medical Officer was authorized an $£ 100$ allowance above his scale for serving in Thorne-Thorne's absence; the Metropolitan Poor Law Inspector was placed on a scale of $£ 500-£ 900$. To clear arrears, the Treasury consented to employ two Medical Inspectors for one year at a salary of $£ 500 .{ }^{133}$ The medical press viewed the proceedings with cautious optimism. The British Medical Journal hoped that the Treasury agreement constituted the first step 'towards the constitution

128 Ibid.

129 Thorne-Thorne described a recent case of neglect: 'It is a . . place to which thousands of visitors will be going in a short time seeking health, in which there has been persistently, quarter after quarter, an appalling mortality from diphtheria. We ought, of course, if possible to go and inquire into it, but how to undertake any inquiry into this extremely intricate matter with any prospect of success is a question which I hardly dare contemplate under existing circumstances. Sir Hugh Owen puts on the papers "I agree that the course proposed would be desirable, if the services of a Medical Inspector were available". Well, those sorts of things are, if not of daily, yet of weekly occurrence'. First Report, Mins. Evid., Q.1197.

${ }_{130}$ First Report, Mins. Evid., Q.1202.

131 First Report, Mins. Evid., Q.1265.

122 This gave him a rise of $£ 400$, but still left him with $£ 500$ less than Simon had received.

123 The fact that this salary was significantly less than the 1650 formerly paid to temporary inspectors alarmed Owen; but when he expressed his fear that the salary would be too low to 'secure the services of efficient and desirable candidates' .. . Spring Rice and Mowatt rejected his assumption, and felt that the salary was adequate enough for candidates. 'No doubt they would be young men', Spring Rice added, 'but perhaps none the worse for that'. T.1/13246/22046/1897, Mowatt to Secretary, Local Government Board, 6 October 1897. 


\section{R. M. MacLeod}

of such a Public Health Department as is now obviously required in this country in the interests both of the public and the State'. ${ }^{134}$

It would have been wrong to assume that the Treasury had made a new policy decision on public health; Thorne-Thorne's salary increase, for example, was sanctioned merely on the basis of his international work, with no written acknowledgement of his claims on other grounds. Moreover, the Committee's recommendations were no solution at all to the Department's basic dilemma. The Board had considerable difficulty in finding suitable temporary Inspectors who could be spared, or could afford to take a year off, for Government service, ${ }^{135}$ and the Department hardly had use of their services before the years sanction had expired. Not surprisingly, therefore, by the winter of $1898-99$, ' . . . the arrears have hardly, if at all been met. The demands made upon the medical staff by reason of the current work has rendered this impracticable.'136 The current work alone required more staff and more money. The application of new biological knowledge to sanitary matters required more medical and engineering inspectors, and the occurrence of preventable water borne diseases was beginning to alert hitherto laggard local authorities to the importance of central advice and assistance. Furthermore, the Vaccination Act of 1898, by substituting domiciliary for stational vaccination, had put increased responsibility upon the inspectorate.

Within eighteen months of the 1898 agreement, the Board therefore asked that two further appointments be made and two temporary appointments should be made permanent. ${ }^{137}$ Stephen Spring Rice who had succeeded Bergne at the Treasury refused the first two appointments but sanctioned the second two. ${ }^{188}$ When Francis Mowatt reviewed the Board's appeal for permanent increases, he found the political pressure of 1894 no longer present. Hugh Owen had also retired from office and had been replaced by the elderly Samuel Provis. Mowatt accordingly reapplied the traditional instrument for containing departmental expansion. ${ }^{139}$ Because no outside inquiry, Mowatt admitted, could defeat or check this tendency to expand, ${ }^{140}$

the only real check of this spread of inspection which demoralises the local authorities as much as it burdens the Exchequer is for the Treasury to refuse to increase the vote and thus to force

184 Brit. med. J., 1898, i, p. 711.

${ }^{185}$ Dr. L. W. Darra Mair, the well-known M.O.H. for Croydon Rural District and Dr. Ralph W. Johnston were appointed. Lancet, 1898, ii, p. 499.

ise T.1/94258/559/1899, Provis to Secretary, Treasury, 10 January 1899.

137 Ibid. Provis also requested an extra $£ 100$ for one of the Medical Inspectors "who in the six and a half years since a Second Assistant Medical Officer had been appointed has assumed extra work'. Such an Inspector was thence to be called the 'Senior Medical Inspector'. He also requested substantial additions to the permanent staff of the Engineering, the Architects and the Glycerinated Vaccine Lymph branches.

${ }^{188} \mathrm{He}$ minuted, "that the value of applying technical expertise to sanitary affairs does not impress me, and still less, the idea of an extended advice to local authorities on the conduct of matters for which those authorities are responsible.'T.1/9425B/15479/1899, Spring Rice to Mowatt, 9 October, 1899.

130 'I believe that their work tends to increase and that the staff are very fully occupied; but both the scope and the number of inspections can be extended indefinitely, and they may be conducted with less elaboration and delay.' T.1/9425B/559/1899, Mowatt to Chancellor of the Exchequer, 31 January, 1899.

140 "both Primrose and I left the Committee [of 1887] with the impression that the Local Government Board of Inspectors had much their own way, and were subject to very little control by the Secretary'. This comment alone reveals the cordial relationship that had grown between the permanent and the medical staffs at the Local Government Board and that restriction and delay during Owen's regime owed more to Treasury policy than to the 'secretarial common sense' of departmental officials. T.1/9425B/559/1899. Mowatt Minute, 31 January, 1899. 


\section{The Frustration of State Medicine, 1880-1899}

the Department to keep their activity within bounds. ${ }^{141}$

Mowatt thus committed the Treasury, until his retirement in 1903, to sanction temporary help for existing arrears, but to resist any permanent increase of staff unless such additions were specifically required by fresh legislation. In order 'to diminish the number of applications to the Local Government Board for advice,' Mowatt suggested that the Government should charge for each central inspection. ${ }^{142}$ For six months the matter rested. In September, 1899, the Local Government Board informed the Treasury that Mowatt had missed the point, but the Treasury determined to put a ceiling on the Department's growth. Spring Rice felt that 'the Local Government Board should exercize self restraint in allowing inquiries, especially when the local sanitary body is an effective one, and should encourage lengthiness in all inquiries'. ${ }^{143}$ Mowatt asked the Local Government Board to help by resisting 'any extension of the inspecting staff beyond the point at which its efficient and economical management becomes increasingly difficult', 144 and he sanctimoniously called upon the Medical Department to discourage 'inquiries of which the necessity and importance are not clearly established.'145

This continuing erosion of confidence finally reduced Thorne-Thorne to a physical wreck. In December 1899, he died, ending a long illness and painful memories of Government service. ${ }^{146}$ Buchanan's resignation from the staff seven years earlier, coupled with the evidence of Thorne-Thorne's failure to achieve sustained support for his plans, testified to the hardships of medical administration. But the passage of time brought with it even stronger arguments for Government expenditure on public health. By the end of the century, it was clear that the limited frame of reference permitted to the medical department was no longer adequate. The Times cited the

141 Ibid. Mowat to Secretary, Local Government Board, 8 February 1899. Mowatt told the Chancellor that a warning against inspectoral activity 'so long as it is merely departmental will have little effect,' and asked the Chancellor to tell Chaplin that the Treasury would not allow an indefinite increase in the cost of the Department, and that the Board should 'scrutinize the system of inspectors with a view to such contraction of the activity of the Department as shall bring it within the provision now made by Parliament'.

${ }_{142}$ T.1/9425B/4403/1899. Mowatt to Secretary, Local Government Board, 23 March 1899. Spring Rice hoped that such fees might not only 'diminish the applications to the Local Government Board but also discourage the volunteering of advice by the Local Government Board'. Ibid. Spring Rice to Mowatt, 17 March 1899. The practice of charging fees in suitable cases was already in effect in inquiries analogous to those conducted by the engineering inspectors-e.g. inquiries for local loan sanctions. But as the Board insisted, 'a large part of the time of the Medical Inspectors, is occupied in inspecting vaccination and making investigation with a view to the control and the prevention of disease and death throughout the country generally. Inquiries of this nature, and those into cases where complaint is made of local defect in sanitary administration are rarely made at the request of local authorities; and under the circumstances the Board see no prospect of materially extending the charging of fees to such authorities.'

${ }_{143}$ T.1/9425B/15479/1899, Spring Rice to Mowatt, 9 October 1899.

14 T.1/9425B/15479/1899, Mowatt to Secretary, Local Government Board, 13 October 1899.

116 Ibid.

146 The medical press contributed glowing testaments of his work. See Brit. Med. J., 1899, ii, 17711773; Lancet, 1899, ii, 762-66. The Lancet carried a special leader, which commented that 'Sir Richard Thorne-Thorne at the time of his premature decease was rapidly becoming Minister of Public Health of the Empire', Lancet, 1899, ii, 1749. The Times considered that by his death 'the country had been deprived of a public servant of conspicious ability, whose influence in the promotion of measures calculated to improve the national health it would be difficult to overestimate'. The Times, 1 June 1900. As vividly recalled by his son, Sir Richard was given no rest from departmental business even on his death-bed, to which examiners came requesting evidence for the Tuberculosis Commission. After his death, according to Civil Service rules of the time, no financial allowance was made to his family, which had therefore to forsake their home, and to sell his books and papers. Personal Communication, Dr. Richard Thorne-Thorne, 28 November 1963. 


\section{R. M. MacLeod}

gross sanitary neglect of many local authorities and their loss of millions of pounds annually, 'for want of sufficient medical knowledge or of sufficient attention to medical advice on the part of those with whom has rested the control of the expenditure.'147 It must have hardly come as a surprise to the Treasury to find that the Local Government Board again and again renewed its appeals for funds and for staff and for 'some plan of satisfying the urgent requirements of the Department'. ${ }^{148}$

New methods were needed for dealing with the Treasury, and as the new century opened, fresh possibilities emerged. Under William (later Sir William) Power, ${ }^{149}$ new tactics were devised. For example, the Department began asking not for more doctors, but for non-professional inspectors to act as 'roving agents' on matters which, 'though closely connected with the medical and scientific work of the Board are in the main administrative in character but which have occupied much time of highly skilled experts who might otherwise be more profitably employed.' ${ }^{150}$

Such an officer could be obtained for as little as $£ 400-£ 20-£ 600, £ 200$ below the scale of Medical Inspectors. Predictably, the Treasury favoured the economising character of such a proposal. One Treasury clerk mused that it may be possible hereafter to get another non-professional or two on the same terms appointed in substitution for a professional'. ${ }^{151}$ Although Spring Rice was more wary, and expressed himself against the idea of a large staff growing up under the Medical Officer, Treasury consent was given. ${ }^{152}$ By the end of 1900 , the Department began to fight its way out of an administrative backwater. The next decade witnessd new social pressures for food preservation and regulation, for the regulation of international health, and for legislation arising from Royal Commissions on arsenical poisoning, tuberculosis, water supply, and sewage disposal. In many respects, this new activity revolutionized central government policies towards the local health authorities, towards provision for medical research, and towards the provision of public medical care. The role of the Medical Department in ultimately formulating such policies within the existing framework of Treasury control, testified to the skill of William Power and his famous successor, Sir Arthur Newsholme.

117 The Times, 1 June 1900.

${ }^{148}$ T.1/9572/14114/1900, Kershaw to Secretary, Treasury, 11 August 1900.

140 While the medical press welcomed a scientific epidemiologist to the senior post, The Times was comforted that Power was from the same school of scientific sanitarians 'whose acuteness in the detection of previously unsuspected channels for the diffusion of disease has long ago gained him a very considerable reputation, so that there can be little danger that either the work or the traditions of the office will suffer in his hands, or that the great responsibilities imposed upon him will be other than thoroughly and adequately discharged'. The Times, 1 June 1900; 'As a worker in epidemiology, Mr. Power occupies a very distinguished position, his knowledge and love of natural history being associated with an insight into epidemiological problems in a way the value of which has been duly recognized by the Royal Society, and which led his former chief, the late Richard Thorne-Thorne, to speak of him on more than one occasion as the 'prince of epidemiologists'.' Lancet, 1900, i, 247. Power was replaced by H. F. Parsons, and Parsons by Robert Bruce Low.

${ }^{150}$ In fact, the Board had the man in mind, $C$. J. Huddart, long-time clerk to the Medical Department and currently secretary to the Departmental Committee on Food Preservatives. T.1/9572/14114/ 1900, Kershaw to Secretary, Treasury, 11 August 1900.

${ }_{151}$ T.1/9572/14114/1900. Hewby to Spring Rice, 14 August 1900.

152 T.1/9572/14114/1900, Minute, Spring Rice, 14 August 1900; Mowatt to Secretary, Local Government Board, 7 August 1900. F. H. O. Jerram, then a Second Division clerk with fourteen years' service in the Department, was promoted to the staff post of statistical assistant to the Medical Officer vacated by Huddert. The latter, by analogy with the Poor Law Medical Inspectorate was thereafter styled 'Assistant Inspector'.' T.1/9572/15372/1900, Kershaw to Secretary, Treasury, 5 September 1900. 